\title{
Oligopyridones: preparation and their folding behavior in polar aprotic solvents
}

\author{
Chih-Kai Liang ${ }^{a}$, Po-Shih Wang ${ }^{a}$, Man-kit Leung ${ }^{\text {a,b,* }}$ \\ a Department of Chemistry, National Taiwan University, 1 Roosevelt Road, Section 4, Taipei 106, Taiwan \\ ${ }^{\mathrm{b}}$ Institute of Polymer Science and Engineering, National Taiwan University, 1 Roosevelt Road, Section 4, Taipei 106, Taiwan
}

\section{A R T I C L E I N F O}

Article history:

Received 14 August 2008

Received in revised form 2 December 2008

Accepted 9 December 2008

Available online 13 December 2008

\section{Keywords:}

Helical structure

Copper reagents

$\mathrm{C}-\mathrm{N}$ coupling

\begin{abstract}
A B S T R A C T
The oligomerization of 5-bromo-2-hydroxypyridine through a Cul catalyzed one-pot condensation tactics was developed. A series of oligopyridones, from dipyridione to penta-pyridone, were therefore synthesized via the CuI-promoted $\mathrm{C}-\mathrm{N}$ coupling reactions. The oligopyridones favor to have folded conformations in polar aprotic solvents. These were confirmed by using ${ }^{1} \mathrm{H}$ NMR, NOESY, and 1D-NOE experiments.
\end{abstract}

(c) 2008 Elsevier Ltd. All rights reserved.

\section{Introduction}

Folding of organic molecules into three-dimensional tertiary structures is important self-organization phenomena of proteins, nucleic acids, and oligosaccharides. The molecular folding process could be governed by static or dynamic reasons. The design of foldamers provided valuable models for investigation of these phenomena and allowed researchers to identify those major interactions for the folding process. ${ }^{1}$ In addition, folding of polymers provided synthetically simple means of architectures that could potentially rival the biopolymers in their complexity and functionality. ${ }^{2}$ It is therefore no surprise that researches on foldamers have received increasing attention in biomimetic and synthetic super-molecular systems. ${ }^{1 \mathrm{f}, \mathrm{g}, 3}$ Many important factors including covalent conformational restrictions, ${ }^{4}$ metal complexation, ${ }^{5}$ solvophobic $^{6}$ and dipolar effects, ${ }^{7}$ chirality-induced folding, ${ }^{6 c, 8,9}$ intermolecular interactions, ${ }^{6 \mathrm{~b}, 10}$ and non-bonding intramolecular interactions ${ }^{1 \mathrm{~h}, 11}$ were identified.

In our ongoing efforts to develop the copper-iodide-promoted C-N coupling conditions for organic synthesis, ${ }^{12}$ we successfully devised an iterative approach for preparation of oligopyridones (Scheme 1). ${ }^{12 a}$ The iterative synthetic sequence started from 5bromo-2-tert-butoxypyridine. Copper iodide/trans- $N, N^{\prime}$-dimethylcyclohexane-1,2-diamine (DMCDA) promoted the $\mathrm{C}-\mathrm{N}$ coupling of 2 with 2-hydroxypyridine (1) and gave $\mathbf{3}$, which could be effectively

\footnotetext{
* Corresponding author. Tel.: +886 233661673.

E-mail address: mkleung@ntu.edu.tw (M.-k. Leung).
}

deprotected to afford 4. An additional pyridone ring could then be further introduced by repeating the iterative synthetic sequence to give 5 .

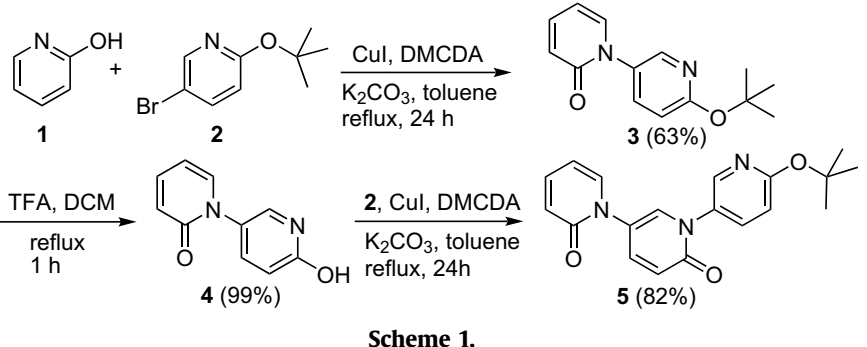

Unfortunately, when we attempted to apply the synthetic sequence for the higher oligopyridone homologues, the synthetic yields were not ideal. Therefore, new strategies for the higher oligopyridone homologues were desired. Herein we report modified procedures for the sequential and one-pot synthesis of the oligopyridones, and the study of their folding behavior in polar aprotic solvents.

\section{Results and discussion}

When the original $\mathrm{C}-\mathrm{N}$ coupling conditions were applied to transform 6 to 7, the synthetic yield dropped to 5\%. Even after changing the solvent from the non-polar toluene to the polar 

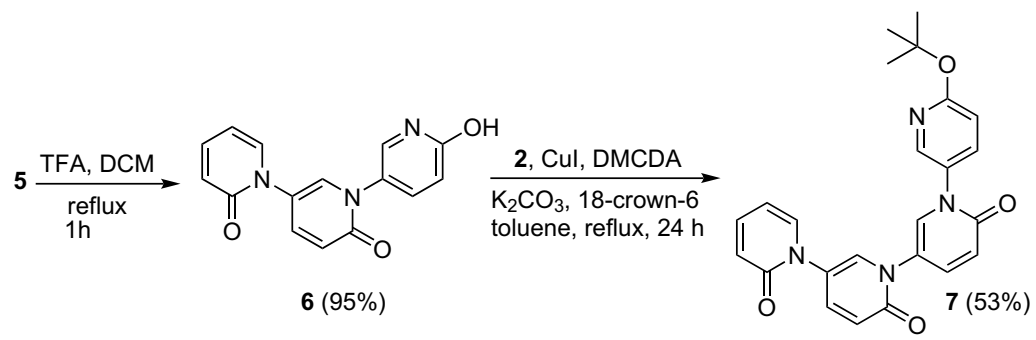

Scheme 2.

aprotic DMF, the synthetic yield slightly increased to $11 \%$. In order to further enhance the solubility and reactivity of $\mathrm{K}_{2} \mathrm{CO}_{3}, 18$-crown6 was adopted as the co-catalyst. Under these conditions, the synthetic yield of 7 was improved to $53 \%$ (Scheme 2). Desiccation of 18-crown- 6 was a crucial requirement for obtaining good yields. If 18-crown-6 was not desiccated appropriately before use, the reaction yield dramatically dropped back to $17 \%$. might be terminated by hydro-debromination at the early stage, giving the dimeric pyridone $\mathbf{3}$ as a predominant product.

To improve the oligomerization, more effective $\mathrm{C}-\mathrm{N}$ coupling conditions were desired to overwhelm the hydro-debromination. Since the CuI/DMCDA ratio could be a crucial factor for the reaction, we adjusted their ratio in order to optimize the yields. Indeed, the use of CuI/DMCDA in a ratio of 0.2 equiv/ 0.16 equiv did not effec-

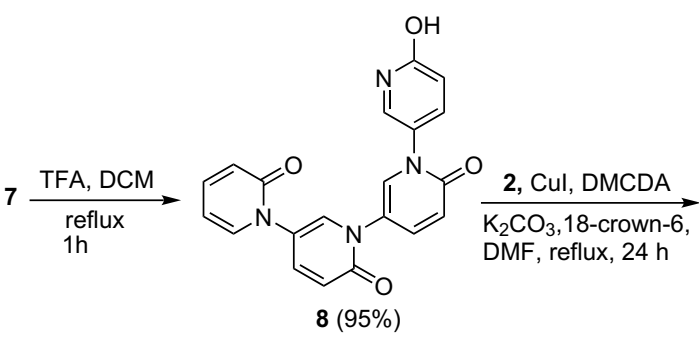

Scheme 3.<smiles></smiles>

$9(18 \%)$
Surprisingly, when the same conditions were applied to convert 8 to 9 , the synthetic yield dropped again to $18 \%$ (Scheme 3). Since the iterative synthetic sequence was definitely time-consuming and became less effective while being extended to higher homologues, more simple ways to get $\mathbf{9}$ were therefore desired.

In the next trial, we attempted to self-condense 2-hydroxy-5bromopyridine to give the oligomeric product in one pot. In this reaction, limited amounts of 2-tert-butoxy-5-bromopyridine were added to construct the tert-butyl protected terminal (Scheme 4). Several inorganic bases, including $\mathrm{K}_{2} \mathrm{CO}_{3}, \mathrm{~K}_{3} \mathrm{PO}_{4}, \mathrm{Cs}_{2} \mathrm{CO}_{3}$, and $\mathrm{Na}_{2} \mathrm{CO}_{3}$, had been tried and only $\mathrm{K}_{2} \mathrm{CO}_{3}$ and $\mathrm{K}_{3} \mathrm{PO}_{4}$ would result in reasonable yields.

When $\mathrm{K}_{2} \mathrm{CO}_{3}$ was used, the hydro-debrominated oligopyridones $\mathbf{3}, \mathbf{5}$, and $\mathbf{7}$ were isolated, respectively, in $22 \%, 15 \%$, and $9 \%$. Similar product distribution was obtained when $\mathrm{K}_{3} \mathrm{PO}_{4}$ was used. These results indicated that the chain growth of the oligomerization tively result in any oligomerization products. However, as mention in Scheme 4 , increasing the ratio to 0.2 equiv/ 0.2 equiv successfully facilitated the reaction to give 3,5 , and 7 in $22 \%, 15 \%$, and $9 \%$, respectively. Further raising the amounts of DMCDA to 0.4 equiv afforded 3, 5, and $\mathbf{7}$ in 14\%, 19\%, and 10\% yields. The increasing yields of the higher homologues of $\mathbf{5}$ and $\mathbf{7}$ implied that the turn over number for the oligomerization increased when the ratio of DMCDA to CuI increased. We attributed these results to the competitive complex formation between CuI and hydroxypyridine that inhibited the formation of the active CuI/DMCDA complex. The activity was therefore diminished. To maintain the catalytic power of the active complex, higher equivalence of DMCDA was necessary to secure the active complex formation. ${ }^{13}$

Another tactic for improving the oligomerization efficiency is to suppress the hydro-debromination. Since the moisture contents in the reaction mixture might accelerate the hydro-debromination,

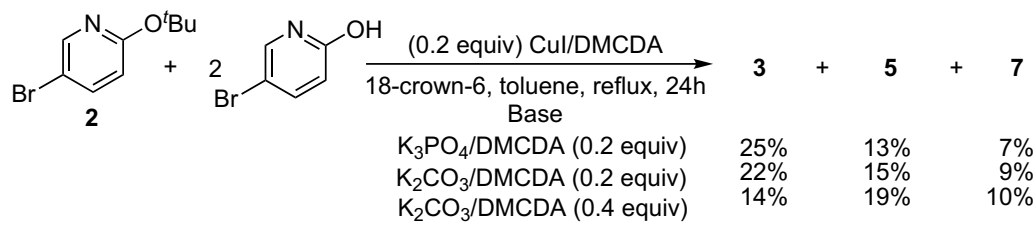

Scheme 4. 
we desiccated all reagents and solvents before use. Under the anhydrous conditions, besides 3, 5, and 7, 10 and 11 were isolated, respectively, in $12 \%$ and $30 \%$ yields (Scheme 5). Formation of $\mathbf{1 1}$ was of particularly interesting because this implied the occurrence of the self-coupling of 2-hydroxy-5-bromopyridine under the reaction conditions.

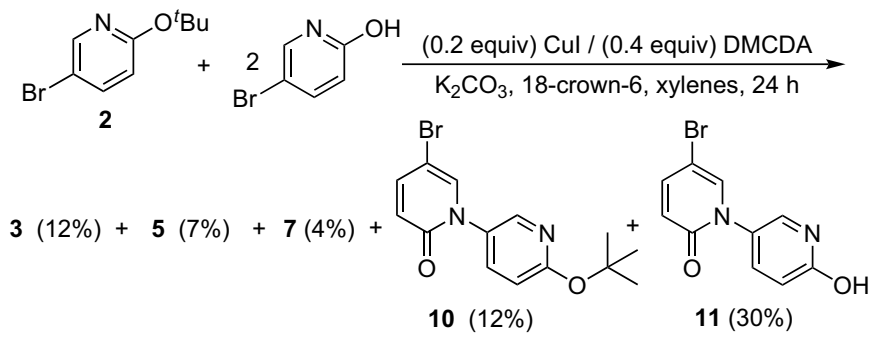

Scheme 5.

We therefore attempted to oligomerize the un-protected 2-hydroxy-5-bromopyridine under similar anhydrous conditions in one pot, using 2-hydroxypyridine as the terminal groups to afford 4, 6 , and $\mathbf{8}$ (Scheme 6). Although the higher homologues could not be isolated from the oligomerization process, the synthesis could be still be accelerated by first preparing tetramer $\mathbf{8}$ in the one-pot condensation, followed by using the Cul catalyzed coupling reaction with 2-tert-butoxy-5-bromopyridine to afford $\mathbf{9}$.

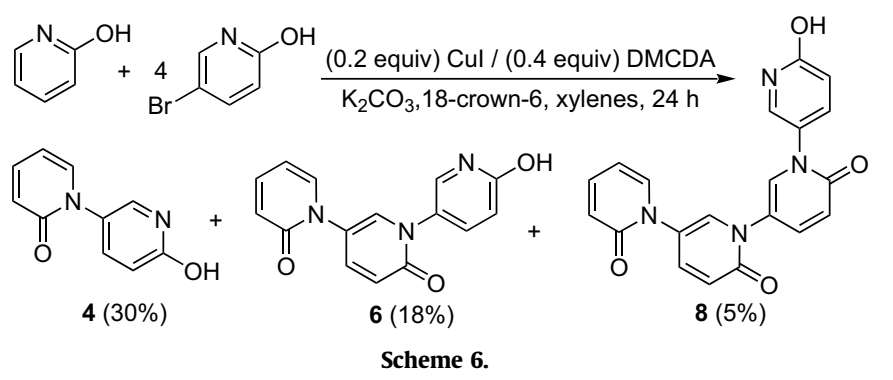

\subsection{Conformational analysis by semi-empirical calculations}

The conformational analyses were performed using semi-empirical PM5 calculations. In our systems, the pyridone moieties were connected through the nitrogen atom of one ring to C-4 of the other ring. Although the pyridine units might favor to have a planar conformation due to the $\pi$-resonance delocalization, presumably as a consequence of the steric repulsions between the $\mathrm{C}=\mathrm{O}^{\prime}$ and the ortho $\mathrm{H}-3$ and $\mathrm{H}-5$, the pyridone rings were found to be non-planar. As a result, four atropisomeric conformers could be identified, among which two of them were essential for the folded conformations and the other two would lead to the extended conformations (Fig. 1).

\section{Folded Conformations}

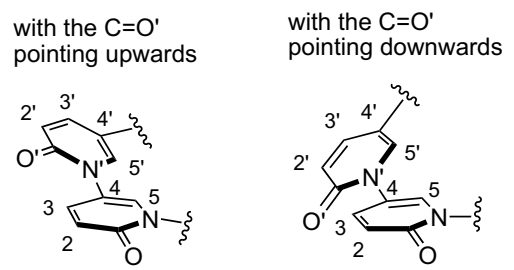

To further understand the relative stability of each conformations, we adopted the corresponding bipyridone as our model to study. In the folded conformations, an estimated distance of $2.84 \AA$ between $\mathrm{H}(5)$ and $\mathrm{H}\left(5^{\prime}\right)$ was obtained, which was shorter than that of $4.14 \AA$ for $\mathrm{H}\left(5^{\prime}\right) \cdots \mathrm{H}(5)$ in the extended conformations. Our PM5 calculations also revealed that the folded and extended conformations would have the estimated heat of formations of -33.0 and $-34.0 \mathrm{kcal} / \mathrm{mol}$, with the dihedral angles of $64.5^{\circ}$ and $124.3^{\circ}$ for $\mathrm{C}\left(5^{\prime}\right)-\mathrm{N}^{\prime}-\mathrm{C}(4)-\mathrm{C}(5)$, respectively. The extended conformations were found to be slightly more stable than the folded conformations by $1 \mathrm{kcal} / \mathrm{mol}$. Either the calculated $\mathrm{C}=\mathrm{O}^{\prime} \cdots \mathrm{H}(3)$ distance of $2.79 \AA$ in the folded conformers or the $\mathrm{C}=\mathrm{O}^{\prime} \cdots \mathrm{H}(5)$ distance of $2.78 \AA$ in the extended conformers would allow the $\mathrm{O}^{\prime} \cdots \mathrm{H}-\mathrm{C}$ intramolecular hydrogen bond interactions.

When three pyridone rings were connected, two types of diastereomeric conformations that are important for occurrence of the molecular folding could be identified (Fig. 2): (a) pyridone rings were aligned in a unique direction so that the terpyridone regime would form a helical twist; (b) pyridone rings were aligned in an opposite direction. Similar situations also occurred for the extended conformations.

When we expanded our theoretical treatments to the pentapyridone, several special conformers, including the fully extended or the fully folded conformers, could be identified. Similar to the previous results, the fully extended conformations were found to be slightly more stable than the fully folded ones.

Three selected representations of the penta-pyridone are shown in Figure 3 for discussion. Figure 3a shows an extended conformer with the pyridone units aligned in a linear way. The calculated heat of formation obtained was $-62.0 \mathrm{kcal} / \mathrm{mol}$. Figure $3 \mathrm{~b}$ shows the conformer of the folded form with the carbonyl groups aligned in an alternating way of up and down. The heat of formation obtained was $-57.5 \mathrm{kcal} / \mathrm{mol}$. Figure $3 \mathrm{c}$ shows the conformer of the folded form with the carbonyl groups aligned in a helical way. The heat of formation obtained was $-58.6 \mathrm{kcal} / \mathrm{mol}$. The linear conformer is relatively stable than the fully curled conformations by around 3-4 kcal/mol according to the results of our calculations.

\section{2. ${ }^{1} \mathrm{H}$ NMR and NOE analysis}

Since the oligopyridones contain a polar array of carbonyl groups, their conformational equilibriums may be highly solvent dependent. Although the extended conformations were predicted to be more stable by our calculations, the polar interactions between the carbonyl groups and the solvent molecules might drive the $\mathrm{C}=\mathrm{O}$ groups pointing outwards to lead to a coiling structure with the hydrophobic interior pointing toward the helical axis. Therefore, we wondered if the folding behavior of the oligopyridones could be tuned by using the solvent effects.

To examine the solvent effects on $\mathbf{5}$, we first subjected 5 to ${ }^{1} \mathrm{H}$ NMR analysis in various deuterated solvents, including $\mathrm{CD}_{2} \mathrm{Cl}_{2}$, $\mathrm{CDCl}_{3}, \mathrm{CD}_{3} \mathrm{CN}$, acetone- $d_{6}$, DMSO- $d_{6}$, and $\mathrm{CD}_{3} \mathrm{OD}$ at $298 \mathrm{~K}$. In good agreement with our predictions, their ${ }^{1} \mathrm{H}$ NMR spectra really

\section{Extended Conformations}

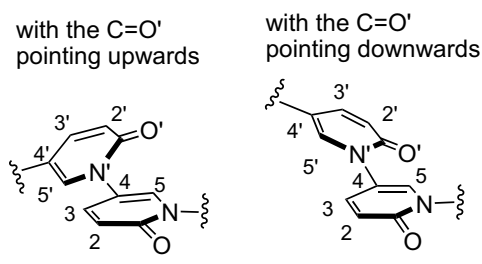

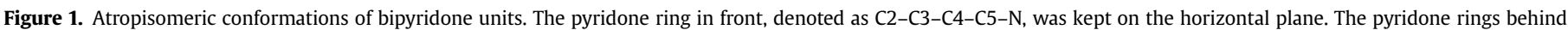
with the $\mathrm{C}=\mathrm{O}$ ' pointing upward and downward were illustrated. 
<smiles>[R9][R9]</smiles>

Pyridone rings are aligned at in a helical way so that the $\mathrm{C}=\mathrm{O}^{\prime}$ on ring $\mathrm{A}$ is pointing upwards with respect to ring $B$ and the $\mathrm{C}=\mathrm{O}^{*}$ is also pointing upward with respect to ring $\mathrm{C}$

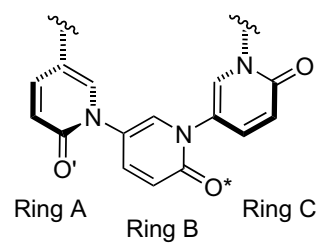

Pyridone rings are aligned alternatively so that when the $C=O^{\prime}$ on ring $A$ is pointing upwards with respect to ring $B$ the $\mathrm{C}=\mathrm{O}^{*}$ is also pointing downward with respect to ring $\mathrm{C}$

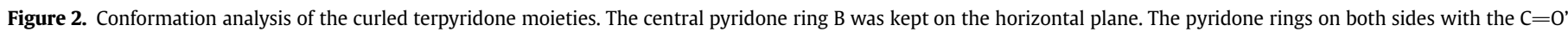
pointing upward and downward were illustrated.

showed high solvent dependency (Fig. 4). Due to the aromatic anisotropic effect as well as the high electronegativity of the nitrogen atom, the outmost pyridinyl $\mathrm{H}(\mathrm{a})$ appeared at the most down-field region of $8.1-8.3 \mathrm{ppm}$. The $\delta \mathrm{H}(\mathrm{a})$ shifted slightly by about $0.14 \mathrm{ppm}$, from $8.10 \mathrm{ppm}$ in $\mathrm{CD}_{2} \mathrm{Cl}_{2}$ to $8.24 \mathrm{ppm}$ in acetone- $d_{6}$. Similar situation was observed for $\delta \mathrm{H}(\mathrm{j})$. On the other hand, $\delta \mathrm{H}(\mathrm{b})$ shifted by about $0.52 \mathrm{ppm}$ from $7.46 \mathrm{ppm}$ in $\mathrm{CD}_{2} \mathrm{Cl}_{2}$ to $7.98 \mathrm{ppm}$ in acetone- $d_{6}$. Since the outmost protons were only shifted slightly in various solvents, the large shift of $\delta \mathrm{H}(\mathrm{b})$ could not be simply explained by the solvation effects. This result indicated that the environment of $\mathrm{H}(\mathrm{b})$ was highly solvent dependent. It is noteworthy to mention that the ${ }^{1} \mathrm{H}$ NMR patterns of $\mathbf{5}$ could be classified into two categories: the spectra of $\mathbf{5}$ in less polar solvents, such as $\mathrm{CD}_{2} \mathrm{Cl}_{2}$ or $\mathrm{CDCl}_{3}$, are grouped in one category. Their ${ }^{1} \mathrm{H}$ NMR spectra were relatively similar. The chemical shifts of $\delta \mathrm{H}(\mathrm{b})$ appeared in the much up-field region, at around 7.4-7.5 ppm. On the other hand, the spectra of 5 in polar solvents such as $d_{6}$-DMSO, $d_{6}$-acetone, or $\mathrm{CD}_{3} \mathrm{OD}$ are relatively similar, in which the chemical shifts of $\delta \mathrm{H}(\mathrm{b})$ appeared in the much down-field region, at around 7.82-7.98 ppm.

To further understand the conformational preference of $\mathbf{5}$ in polar environment, we selected DMSO- $d_{6}$ as the solvent to study (Fig. 5). The ${ }^{1} \mathrm{H}$ NMR of 5 in DMSO- $d_{6}$ show 10 sets of well-separated aromatic and vinyl signals that fall into three groups. The COSY experiments correlated: (1) $\mathrm{H}(\mathrm{c}), \mathrm{H}(\mathrm{d}), \mathrm{H}(\mathrm{e})$, and $\mathrm{H}(\mathrm{f})$ to ring
A; (2) $\mathrm{H}(\mathrm{b}), \mathrm{H}(\mathrm{g})$, and $\mathrm{H}(\mathrm{h})$ to ring $\mathrm{B}$; and (3) $\mathrm{H}(\mathrm{a}), \mathrm{H}(\mathrm{i})$, and $\mathrm{H}(\mathrm{j})$ to ring $C$. The assignments of protons on ring $C$ were further confirmed by the NOE experiments which correlated $\mathrm{H}(\mathrm{j})$ to the tertbutyl protons. The correlations among $\mathrm{H}(\mathrm{a}), \mathrm{H}(\mathrm{b})$, and $\mathrm{H}(\mathrm{c})$ were also examined by NOE difference spectroscopy. When $\mathrm{H}(\mathrm{a})$ was selectively double irradiated (spin-decoupling), NOE enhancement on $\mathrm{H}(\mathrm{b})$ occurred (Fig. 5, spectrum I), indicating that $\mathrm{H}(\mathrm{b})$ and $\mathrm{H}(\mathrm{a})$ are within a close distance to each other. On the other hand, when $\mathrm{H}(\mathrm{b})$ was double irradiated, NOE on $\mathrm{H}(\mathrm{a}), \mathrm{H}(\mathrm{c})$, and $\mathrm{H}(\mathrm{i})$ were observed (Fig. 5, spectrum II). The NOE on $\mathrm{H}(\mathrm{a})$ was higher in comparison to that of $\mathrm{H}(\mathrm{i})$, with a ratio of $1: 0.79$. This result indicated that the average distance between $\mathrm{H}(\mathrm{a}) \cdots \mathrm{H}(\mathrm{b})$ might be shorter than that of $\mathrm{H}(\mathrm{i}) \cdots \mathrm{H}(\mathrm{b})$. Selective irradiation on $\mathrm{H}(\mathrm{c})$ without affecting $\mathrm{H}(\mathrm{i})$ was almost impossible in our cases due to the pulsewidth problem. Therefore we adopted the 2-D NOESY experiment in which strong correlation among $\mathrm{H}(\mathrm{c}), \mathrm{H}(\mathrm{d})$, and $\mathrm{H}(\mathrm{b})$ and weaker correlation between $\mathrm{H}(\mathrm{c})$ and $\mathrm{H}(\mathrm{g})$ were clearly shown.

Similarly, ${ }^{1} \mathrm{H}$ NMR assignments in acetone- $d_{6}$ for 7 were achieved using ${ }^{1} \mathrm{H}-{ }^{1} \mathrm{H}$ COSY and NOESY techniques (Fig. 6). Although the coupling patterns and the chemical shifts of the protons on ring $B$ and ring $C$ were very similar, they could be distinguished by NOE: (i) when $\mathrm{H}(\mathrm{a})$ was irradiated, signal enhancement occurred on $\mathrm{H}(\mathrm{b})$ along with decoupling on $\mathrm{H}(\mathrm{l})$ and $\mathrm{H}(\mathrm{m})$ (Fig. 6I); (ii) when $\mathrm{H}(\mathrm{b})$ was irradiated, signal enhancements on $\mathrm{H}(\mathrm{a}), \mathrm{H}(\mathrm{c})$, and $\mathrm{H}(\mathrm{l})$, with the
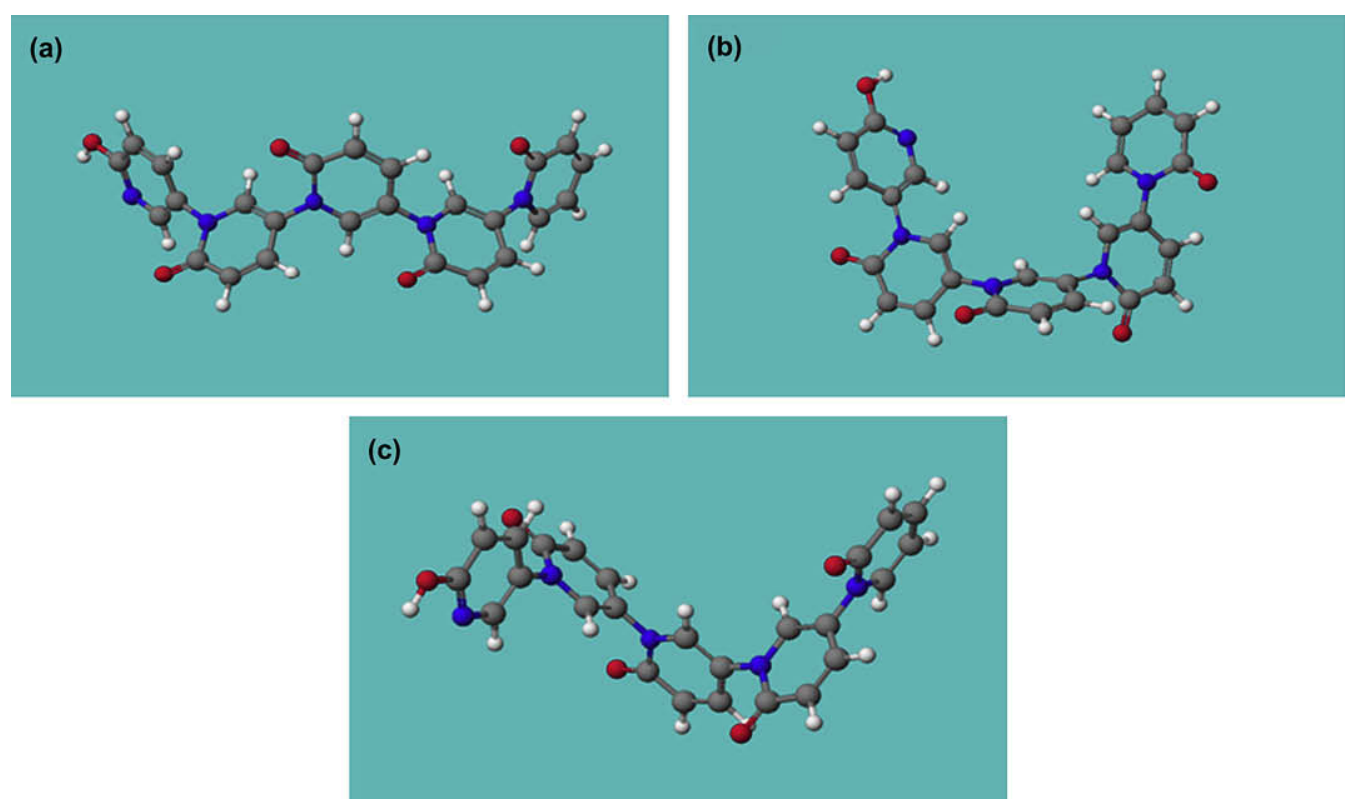

Figure 3. Selected representations of the penta-pyridone: red for oxygen; blue for nitrogen; black for carbon. 


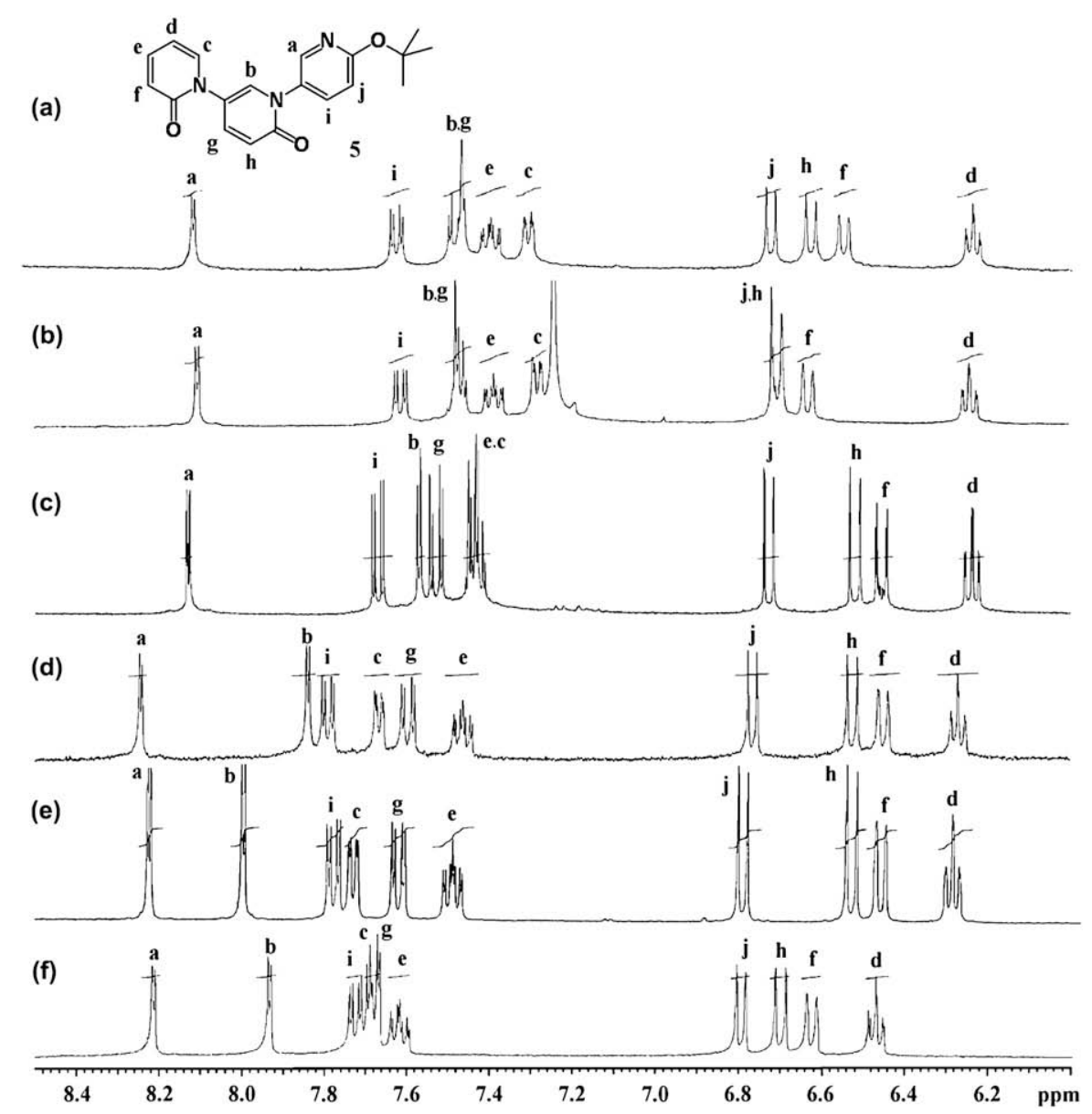

Figure 4. ${ }^{1} \mathrm{H}$ NMR of 5 in various deuterated solvents, including (a) $\mathrm{CD}_{2} \mathrm{Cl}_{2}$, (b) $\mathrm{CDCl}_{3}$, (c) $\mathrm{CD}_{3} \mathrm{CN}$, (d) acetone- $d_{6}$, (e) DMSO- $d_{6}$, and (f) $\mathrm{CD}_{3} \mathrm{OD}$ at $298 \mathrm{~K}$.

relative ratio of 1.00:0.16:0.51, were observed, along with decoupling on $\mathrm{H}(\mathrm{j})$ and $\mathrm{H}(\mathrm{k})$ (Fig. $6 \mathrm{II})$. The observation of the relatively strong NOE on $\mathrm{H}(\mathrm{a})$ over $\mathrm{H}(\mathrm{l})$ (1:0.51) in Figure 6II suggested that the average distance between $\mathrm{H}(\mathrm{b}) \cdots \mathrm{H}(\mathrm{a})$ is shorter than that of
$\mathrm{H}(\mathrm{b}) \cdots \mathrm{H}(\mathrm{l})$; (iii) when $\mathrm{H}(\mathrm{c})$ was irradiated, signal enhancements on $H(b), H(j)$, and $H(d)$, with the relative ratio of $1.00: 0.46: 1.48$, were observed along with decoupling on $\mathrm{H}(\mathrm{h})$ and $\mathrm{H}(\mathrm{i})$ (Fig. 6III). Similarly, stronger NOE on $\mathrm{H}(\mathrm{b})$ over $\mathrm{H}(\mathrm{j})(1: 0.46)$ again indicated that

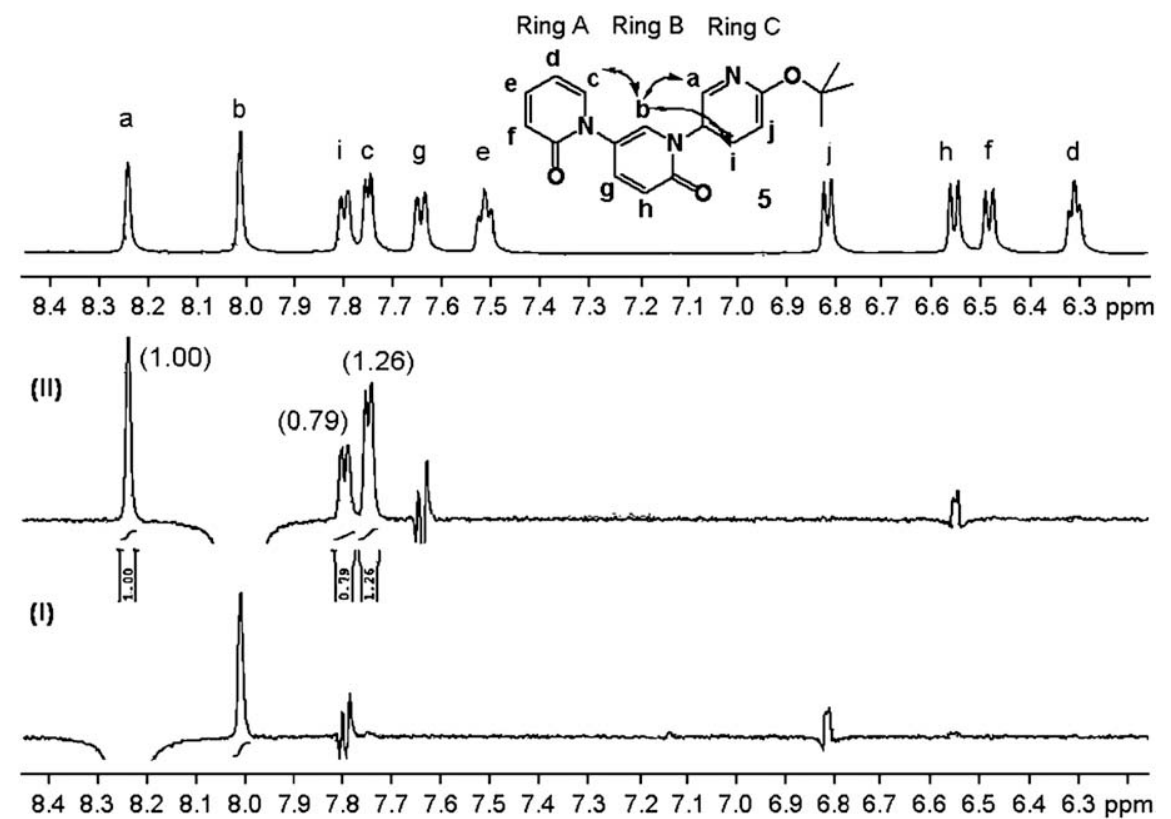

Figure 5. ${ }^{1} \mathrm{H}$ NMR assignments and NOE experiments for 5: (I) selectively irradiated at H(a); (II) selectively irradiated at H(b) at $298 \mathrm{~K}$. 


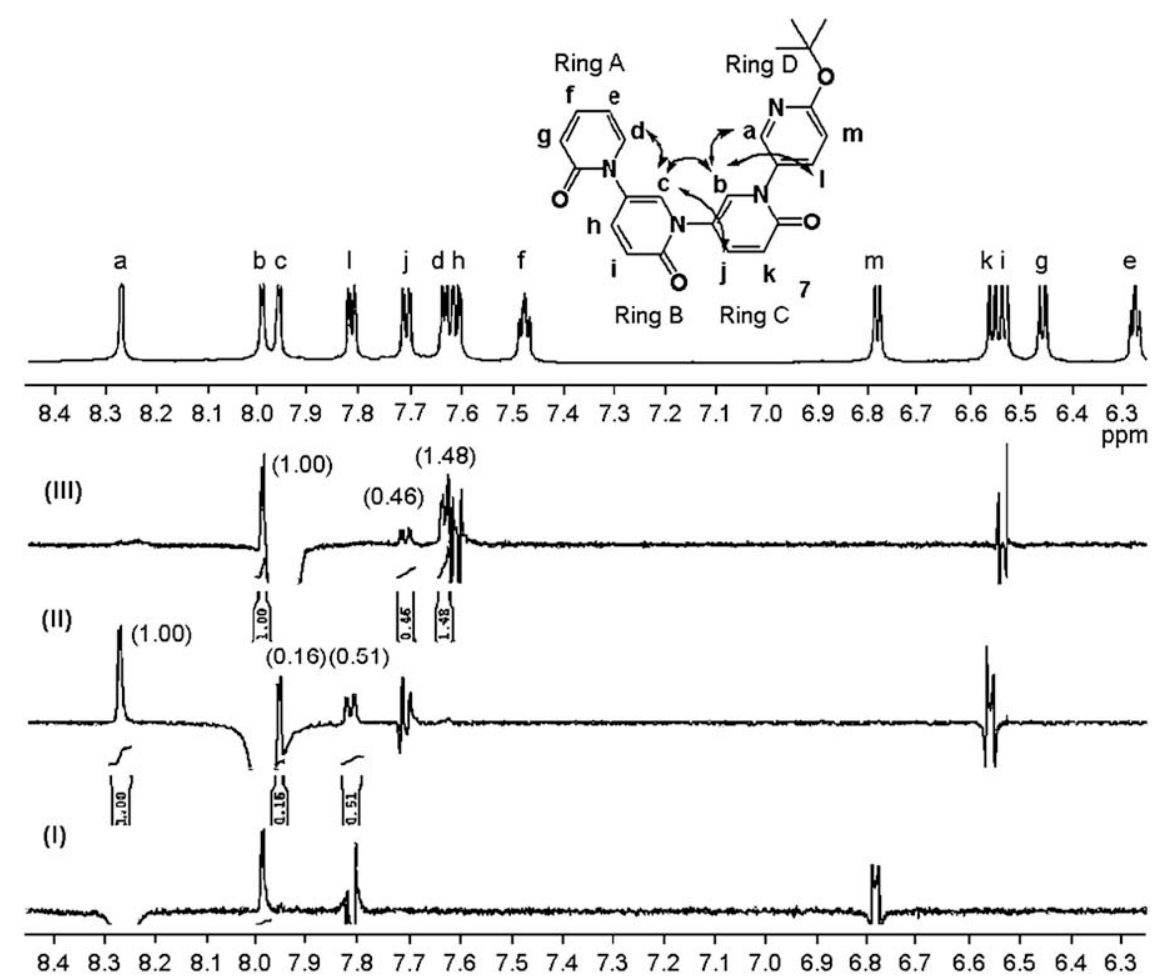

Figure 6. ${ }^{1} \mathrm{H}$ NMR assignments and NOE experiments for 7: (I) selectively irradiated at H(a); (II) selectively irradiated at H(b); (III) selectively irradiated at H(c) at $298 \mathrm{~K}$.

$\mathrm{H}(\mathrm{c})$ stayed closer to $\mathrm{H}(\mathrm{b})$ rather than to $\mathrm{H}(\mathrm{j})$. All of these observations supported the assumption of having folded conformations for $\mathbf{7}$ in the polar aprotic solvents. However, due to the small chemical shift's differences between $H(d)$ and $H(h)$, selectively double irradiation on $\mathrm{H}(\mathrm{d})$ without affecting $\mathrm{H}(\mathrm{h})$ became difficult to achieve.

By applying similar NOE difference spectroscopy and ${ }^{1} \mathrm{H}-{ }^{1} \mathrm{H}$ COSY techniques, the ${ }^{1} \mathrm{H}$ NMR assignments for $\mathbf{9}$ could

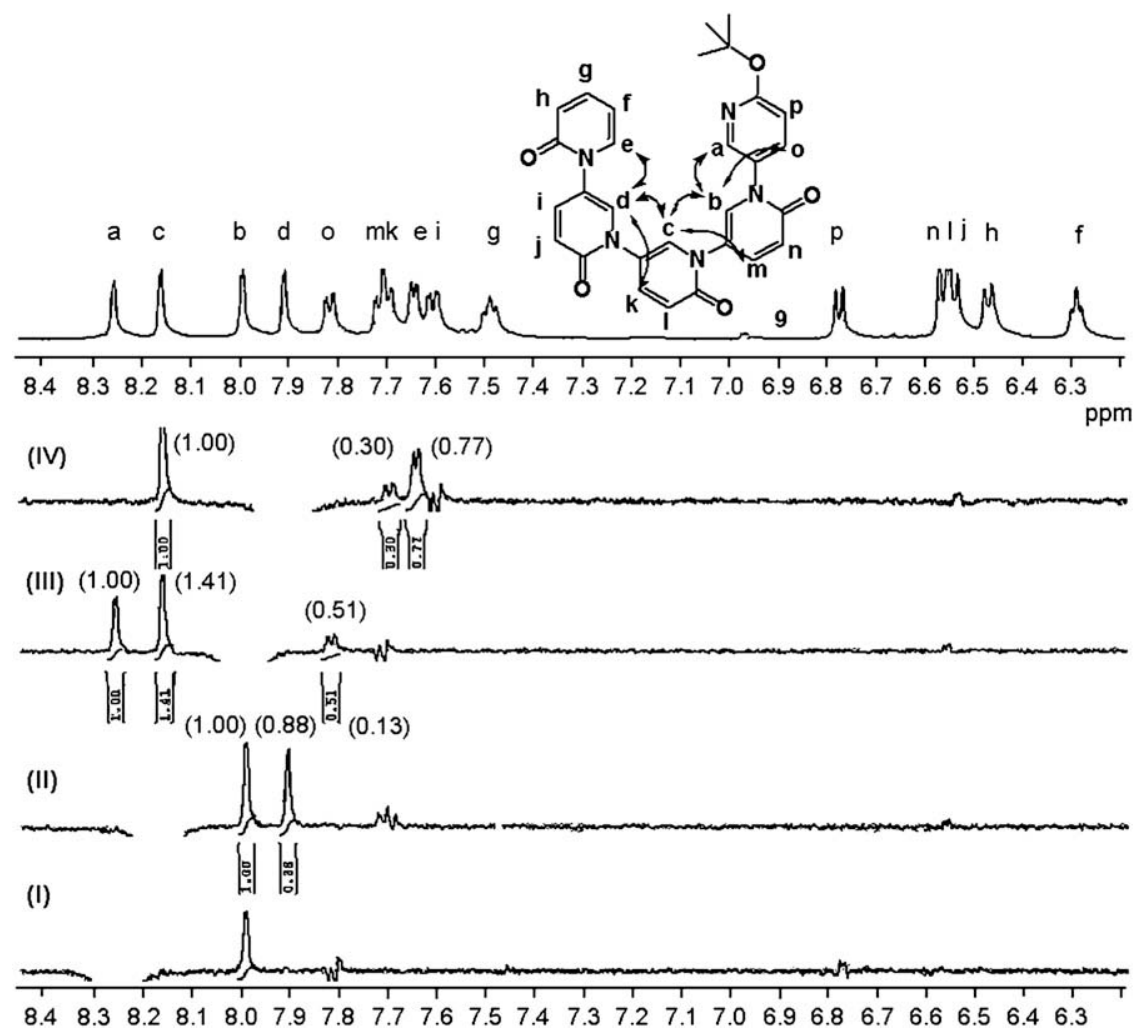

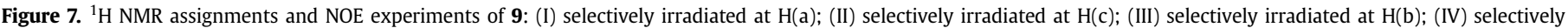
irradiated at $\mathrm{H}(\mathrm{d})$ at $298 \mathrm{~K}$. 


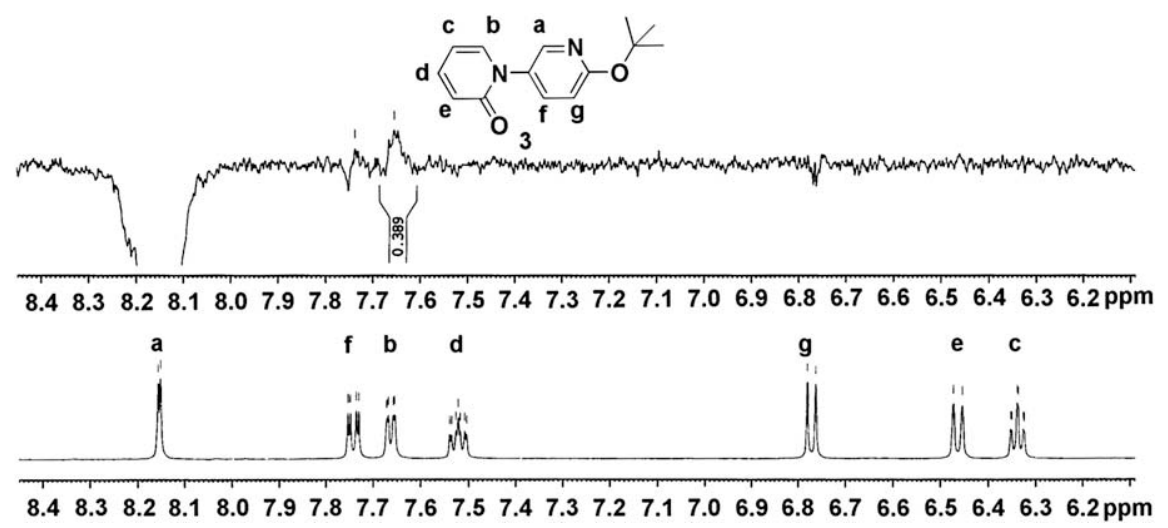

Figure 8. NOE spectrum of 3 in acetone- $d_{6}$ at $223 \mathrm{~K}$. Signal enhancement on H(b) was observed when H(a) was irradiated.

unambiguously achieved as depicted in Figure 7. Again, observations of the preferential NOE enhancements on $\mathrm{H}(\mathrm{a})$ over $\mathrm{H}(\mathrm{o})$ (1:0.51), $\mathrm{H}(\mathrm{b})$ over $\mathrm{H}(\mathrm{m})$ (1: 0.13 ), and $\mathrm{H}(\mathrm{c})$ over $\mathrm{H}(\mathrm{k})$ (1:0.30) suggested that 9 prefers to have the folded conformation over the extended form. However, due to the small chemical shift's difference between $\mathrm{H}(\mathrm{e})$ and $\mathrm{H}(\mathrm{i})$, selective irradiation on $\mathrm{H}(\mathrm{e})$ without affecting $\mathrm{H}(\mathrm{i})$ became difficult to achieve.

On the contrary, when the dimeric pyridone $\mathbf{3}$ was subjected to NOE measurement at $298 \mathrm{~K}$ in acetone- $d_{6}$, no NOE signals could be observed. This is probably due to the fast rotation of the rings about the $\mathrm{C}-\mathrm{N} \sigma$-bond. To further obtain more evidences to support this argument, the NOE measurement was carried out at $223 \mathrm{~K}$ $\left(-50^{\circ} \mathrm{C}\right)$. Under this circumstance, weak NOE signal on $\mathrm{H}(\mathrm{b})$ was observed when $\mathrm{H}(\mathrm{a})$ of $\mathbf{3}$ was irradiated (Fig. 8). Similar NOE correlation was also observed in the $2 \mathrm{D}-\mathrm{NOESY}$ spectrum at $223 \mathrm{~K}$. This result suggested that our previous assumption about the fast $\mathrm{C}-\mathrm{N}$ $\sigma$-bond rotation is correct. Since the NOE on the higher oligopyridone homologues could clearly be observed, this indicated that the fast $\sigma$-bond rotation along the $\mathrm{C}-\mathrm{N}$ bond was slowed down in folded oligopyridones.

The conformational preference of the oligopyridones in nonpolar solvents is also important to know. However, due to the small chemical shift differences between the vinyl protons in non-polar solvents such as $\mathrm{CD}_{2} \mathrm{Cl}_{2}$ and $\mathrm{CDCl}_{3}$, it is very difficult to selectively double irradiate one proton without touching the adjacent ones. This limited our chance to fully evaluate their conformational preferences in non-polar solvents. Nevertheless, we have attempted using $\mathbf{5}$ as our target to study. Different from the observations in polar solvents, we discovered that NOE enhancements on $\mathrm{H}(\mathrm{b})$ and $\mathrm{H}(\mathrm{g})$ were simultaneously observed when $\mathrm{H}(\mathrm{a})$ was double irradiated in $\mathrm{CDCl}_{3}$ (Fig. 9). This could be rationalized if we assumed that $\mathrm{H}(\mathrm{a})$ favored to turn outwards in $\mathrm{CDCl}_{3}$, leading to similar average distances between $\mathrm{H}(\mathrm{a})-\mathrm{H}(\mathrm{b})$ and $\mathrm{H}(\mathrm{a})-\mathrm{H}(\mathrm{g})$. This observation is consistent with our PM3 calculations, which suggested that the distance between $\mathrm{H}(\mathrm{a})-\mathrm{H}(\mathrm{b})$ should be $4.45 \AA$ and the distance between $\mathrm{H}(\mathrm{a})-\mathrm{H}(\mathrm{g})$ should be $4.56 \AA$. In addition, signal enhancement on $\mathrm{H}(\mathrm{h})$ was also observed even though it might be complicated by the decoupling of $\mathrm{H}(\mathrm{j})$.

In summary, our NMR evidence suggested that the conformational equilibriums of oligopyridones $\mathbf{5}, \mathbf{7}$, and $\mathbf{9}$ are solvent dependent. The oligopyridones favored to stay in the folded conformations over the extended ones in highly polar solvents such as DMSO- $d_{6}$ or acetone- $d_{6}$. However, factors that governed the solvent effects on the conformational preference are still unclear. To rationalize this phenomenon, we employed semi-empirical PM5 method to calculate the charge density on the oligopyridones. In our calculations, instead of using the tert-butyl substituted $\mathbf{5}$, an $\mathrm{O}$ methyl substituted tripyridone had been adopted in order to simplify the calculations (Fig. 10). Our results revealed that more negative charge was distributed onto the $\alpha$-carbon atom $C(2)$ rather than onto the nitrogen atom. The result is in good agreement with the resonance theory, in which charge delocalization from the nitrogen lone pair to the carbonyl group is predicted. The charge distributions either on the extended form or on the folded form were found to be similar. In non-polar environment where weak intermolecular solvent-molecule interactions are expected, the conformation of the oligopyridones will be adjusted so as to minimize the intramolecular electrostatic repulsion. As illustrated in Figure 10 , the inter-distance between $\mathrm{O}^{\prime} \cdots \mathrm{C}(2)$ in the extended conformation is longer in comparison to that in the folded

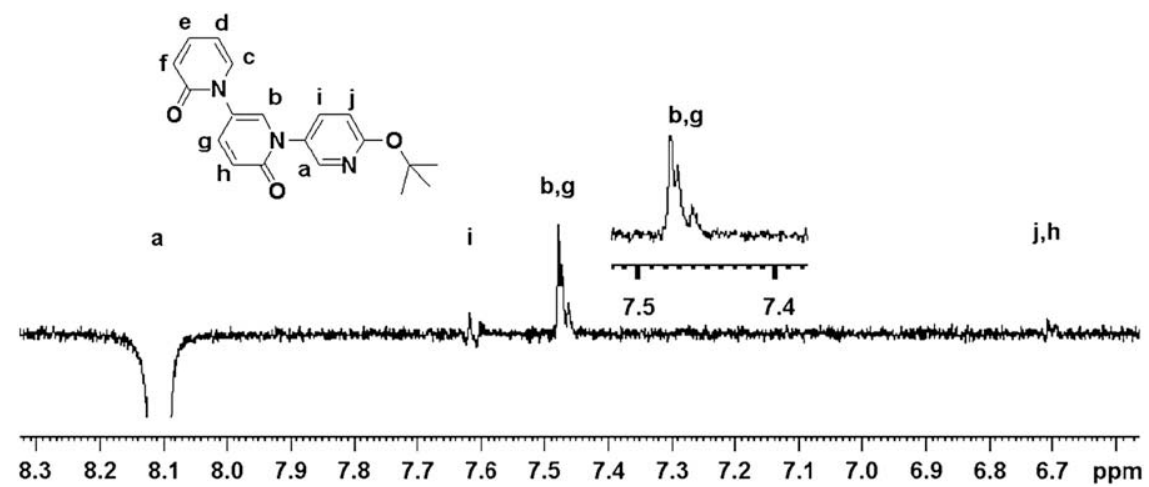

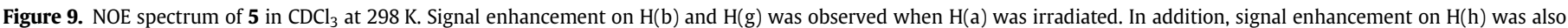
observed. 

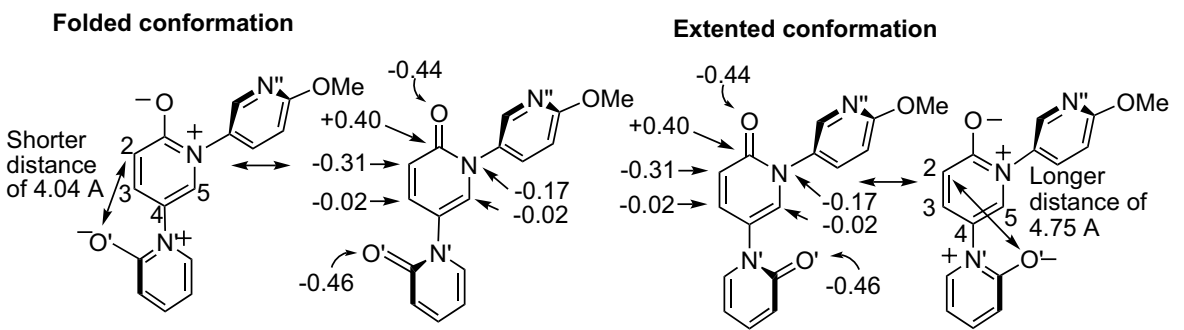

Figure 10. PM5 calculation of the partial charge distribution on the $O$-methyl substituted tripyridone.

conformation. Therefore the extended conformations will become more favorable in less-polar environment. On the other hand, perhaps due to solvent-dipole interactions that may be able to compensate the repulsion in more polar environment, the oligopyridone tends to curl into the folded conformations.

\section{Experimental section}

\subsection{Methods}

${ }^{1} \mathrm{H}$ and ${ }^{13} \mathrm{C}$ NMR were recorded in $\mathrm{CDCl}_{3}$ and chemical shifts were reported in parts per million in relative scale to $\mathrm{CHCl}_{3}(\delta$ $7.24 \mathrm{ppm}$ for ${ }^{1} \mathrm{H}$ and $77.0 \mathrm{ppm}$ for $\left.{ }^{13} \mathrm{C}\right)$. Without being noted, the NMR measurements for the oligopyridones were performed at $298 \mathrm{~K}$ in various solvents, including $\mathrm{CD}_{2} \mathrm{Cl}_{2}, \mathrm{CDCl}_{3}, \mathrm{CD}_{3} \mathrm{CN}$, acetone$d_{6}$, DMSO- $d_{6}$, and $\mathrm{CD}_{3} \mathrm{OD}$. Before use, $\mathrm{CDCl}_{3}$ was treated with $\mathrm{K}_{2} \mathrm{CO}_{3}$ to remove any acidic impurity and dried over $\mathrm{CaH}_{2}$, followed by molecular sieves $4 \mathrm{~A}$, and distilled. $\mathrm{CD}_{3} \mathrm{CN}$, acetone- $d_{6}$, and DMSO$d_{6}$ were dried over $4 \AA$ molecular sieves. $\mathrm{CD}_{3} \mathrm{OD}$ sealed in an ampoule was purchased and directly used after being opened. The concentration of the sample was about $10^{-3} \mathrm{M}$. The NOE, NOESY, and COSY experiments were performed on a Bruker $500 \mathrm{MHz}$ or $600 \mathrm{MHz}$ NMR.

\subsubsection{1-(1-(6-Hydroxypyridin-3-yl)-1,6-dihydro-6-oxopyridin-3-} yl)-1H-pyridin-2-one (6)

To an oven-dried flask $(25 \mathrm{~mL})$ were charged compound $\mathbf{5}(0.5 \mathrm{~g}$ $1.5 \mathrm{mmol}$ ), $\mathrm{CH}_{2} \mathrm{Cl}_{2}$ (8 mL), and trifluoroacetic acid (TFA) (5\%). The reaction mixture was stirred and heated at reflux temperature for $1 \mathrm{~h}$. The resulting solution was concentrated and washed with hexane to give white solid. Note that this compound is hygroscopic and soluble in water. Normal extraction workup procedure is inappropriate in this case. The white solid was dried under vacuum at $110{ }^{\circ} \mathrm{C}$ for overnight to afford $6(0.41 \mathrm{~g}, 95 \%)$ : mp $290-291^{\circ} \mathrm{C} .{ }^{1} \mathrm{H}$ NMR $\left(400 \mathrm{MHz}\right.$, DMSO- $\left.d_{6}\right) \delta 7.95$ (d, $J=2.4 \mathrm{~Hz}$ ), 7.71 (dd, $J=7.6$, $1.8 \mathrm{~Hz}, 1 \mathrm{H}), 7.68(\mathrm{~d}, J=2.8 \mathrm{~Hz}, 1 \mathrm{H}), 7.59(\mathrm{dd}, J=9.6,2.8 \mathrm{~Hz}, 1 \mathrm{H}), 7.54$ (dd, $J=9.4,3.0 \mathrm{~Hz}, 1 \mathrm{H}), 7.49(\mathrm{td}, J=8.0,2.2 \mathrm{~Hz}, 1 \mathrm{H}), 6.50(\mathrm{~d}, 10 \mathrm{~Hz}$, $1 \mathrm{H}), 6.46(\mathrm{dd}, J=10,1.6 \mathrm{~Hz}, 1 \mathrm{H}), 6.38(\mathrm{~d}, J=10 \mathrm{~Hz}, 1 \mathrm{H}), 6.38$ (d, $J=10 \mathrm{~Hz}, 1 \mathrm{H}), 6.29(\mathrm{td}, J=6.4,1.4 \mathrm{~Hz}, 1 \mathrm{H}) ;{ }^{13} \mathrm{C}$ NMR $(100 \mathrm{MHz}$, DMSO- $\left.d_{6}\right) \delta 161.6,161.4,160.5,141.0,140.6,140.3,139.5,136.8,134.0$, $121.8,121.0,120.1,118.9,105.6$ (only 14 separated peaks were found); IR ( $\mathrm{KBr}) 3384,3040,1680(\mathrm{C}=0), 1654,1607,1553,1531$, $1459 \mathrm{~cm}^{-1}$; FAB (NBA) $282.1\left(\mathrm{M}^{+}+\mathrm{H}\right)$; HRMS calcd for $\mathrm{C}_{15} \mathrm{H}_{12} \mathrm{~N}_{3} \mathrm{O}_{3}$ 282.0879, found $282.0869\left(\mathrm{M}^{+}+\mathrm{H}\right)$. Anal. Calcd for $\mathrm{C}_{15} \mathrm{H}_{11} \mathrm{~N}_{3} \mathrm{O}_{3}$ : C, 64.05; H, 3.94; N, 14.94. Found: C, 63.68; H, 4.33; N, 15.21 .

\subsection{2. $6^{\prime \prime \prime}$-tert-Butoxy- $\left[1,3^{\prime}: 1^{\prime}, 3^{\prime \prime}: 1^{\prime \prime}, 3^{\prime \prime \prime}\right]$ quaterpyridine-2, $6^{\prime}, 6^{\prime \prime}$ -}

trione (7)

To an oven-dried (10 $\mathrm{mL}$ ) double-necked flask, denoted as flask A, containing a stir-bar were charged $6(0.5 \mathrm{~g}, 1.77 \mathrm{mmol})$, CuI (20 mol\%), and $\mathrm{K}_{2} \mathrm{CO}_{3}$ (2 equiv). The reagents were heated at $75^{\circ} \mathrm{C}$ under vacuum for $1 \mathrm{~h}$. To another oven-dried (10 mL) double- necked flask was charged with 18-crown-6 (0.094 g, $0.35 \mathrm{mmol})$. The 18 -crown- 6 was dried under vacuum at $100{ }^{\circ} \mathrm{C}$ for $1 \mathrm{~h}$. Toluene $(1 \mathrm{~mL})$ was then injected to dissolve the dried crown ether. The crown ether solution was then injected into the flask $\mathrm{A}$, followed by a solution of 2-tert-butoxy-5-bromopyridine $(0.49 \mathrm{~g}, 2.1 \mathrm{mmol})$ and DMCDA (20 mol \%) in toluene $(1 \mathrm{~mL})$ under nitrogen. The reaction mixture was stirred and heated at reflux temperature for $24 \mathrm{~h}$. The resulting mixture was cooled, diluted with $\mathrm{CH}_{2} \mathrm{Cl}_{2}$, and filtered. The filtrate was washed with water. The organic phase was collected, dried over $\mathrm{MgSO}_{4}$ (anhydrous), and concentrated. The crude product was purified by flash chromatography on silica gel (ethyl acetate $/ \mathrm{MeOH})$ to give white solid $(0.405 \mathrm{~g}, 53 \%)$. Mp $240-241{ }^{\circ} \mathrm{C}$. ${ }^{1} \mathrm{H}$ NMR (400 MHz, DMSO- $\left.d_{6}\right) \delta 8.240(\mathrm{~d}, J=2.8 \mathrm{~Hz}, 1 \mathrm{H}), 8.07(\mathrm{dd}$, $J=4.8,1.2 \mathrm{~Hz}, 2 \mathrm{H}), 7.79$ (dd, $J=8.8,2.4 \mathrm{~Hz}, 1 \mathrm{H}), 7.68-7.73(\mathrm{~m}, 2 \mathrm{H})$, $7.62(\mathrm{dd}, J=9.6,2.8 \mathrm{~Hz}, 1 \mathrm{H}), 7.50(\mathrm{td}, J=8.0,2.0 \mathrm{~Hz}, 1 \mathrm{H}), 6.79(\mathrm{~d}$, $J=8.8 \mathrm{~Hz}, 1 \mathrm{H}), 6.54(\mathrm{t}, J=9 \mathrm{~Hz}, 2 \mathrm{H}), 6.47(\mathrm{~d}, J=9.2 \mathrm{~Hz}, 1 \mathrm{H}), 6.30(\mathrm{td}$, $J=6.8,1.4 \mathrm{~Hz}, 1 \mathrm{H}), 1.564(\mathrm{~s}, 9 \mathrm{H}) ;{ }^{13} \mathrm{C}$ NMR (100 MHz, DMSO- $\left.d_{6}\right)$ $\delta$ 161.7, 160.4, 159.4, 143.1, 140.2, 139.9, 139.6, 138.7, 136.9, 136.0, $135.8,129.7,121.2,120.9,119.5,118.3,112.0,105.0,79.5,28.3$ (only 18 aromatic signals were found); IR (KBr) 3032, 2974, $1681(C=0)$, $1660(\mathrm{C}=\mathrm{O}), 1593,1531,1485 \mathrm{~cm}^{-1}$; FAB (NBA) $431.2\left(\mathrm{M}^{+}+\mathrm{H}\right)$; HRMS calcd for $\mathrm{C}_{24} \mathrm{H}_{23} \mathrm{~N}_{4} \mathrm{O}_{4} 431.1719$, found 431.1733. Anal. Calcd for $\mathrm{C}_{24} \mathrm{H}_{22} \mathrm{~N}_{4} \mathrm{O}_{4}$ : C, 66.97; $\mathrm{H}, 5.15 ; \mathrm{N}, 13.0$. Found: $\mathrm{C}, 66.90 ; \mathrm{H}, 5.07$; $\mathrm{N}, 12.93$.

\subsection{3. $6^{\prime \prime \prime}-$ Hydroxy- $\left[1,3^{\prime}: 1^{\prime}, 3^{\prime \prime}: 1^{\prime \prime}, 3^{\prime \prime \prime}\right]$ quaterpyridine- $2,6^{\prime}, 6^{\prime \prime}$ trione $(\mathbf{8})$}

To an oven-dried flask $(25 \mathrm{~mL})$ were charged $7(0.2 \mathrm{~g}$, $0.46 \mathrm{mmol}), \mathrm{CH}_{2} \mathrm{Cl}_{2}(2 \mathrm{~mL})$, and TFA (5\%). The reaction mixture was stirred and heated at reflux temperature for $1 \mathrm{~h}$. The resulting solution was concentrated and washed with hexane to give white solid. Note that this compound is hygroscopic and soluble in water. Normal extraction workup procedure is inappropriate in this case. The white solid was dried under vacuum at $110^{\circ} \mathrm{C}$ overnight to afford 8 (0.16 g, 95\%). Mp 296-297 ${ }^{\circ} \mathrm{C} .{ }^{1} \mathrm{H}$ NMR (400 MHz, DMSO$\left.d_{6}\right) \delta 8.05(\mathrm{~d}, J=2.4 \mathrm{~Hz}, 1 \mathrm{H}), 8.03(\mathrm{~d}, J=3.2 \mathrm{~Hz}, 1 \mathrm{H}), 7.71-7.73(\mathrm{~m}, 2 \mathrm{H})$, 7.66 (dd, $J=10,2.8 \mathrm{~Hz}, 1 \mathrm{H}), 7.62$ (dd, $J=10,2.8 \mathrm{~Hz}, 1 \mathrm{H}), 7.55$ (dd, $J=9.8,3.2 \mathrm{~Hz}, 1 \mathrm{H}), 7.50(\mathrm{td}, J=8.0,2.0 \mathrm{~Hz}, 1 \mathrm{H}), 6.53(\mathrm{~d}, J=5.2 \mathrm{~Hz}, 1 \mathrm{H})$, $6.50(\mathrm{~d}, J=4.4 \mathrm{~Hz}, 1 \mathrm{H}), 6.47(\mathrm{~d}, J=9.2 \mathrm{~Hz}, 1 \mathrm{H}), 6.39(\mathrm{~d}, J=9.6 \mathrm{~Hz}, 1 \mathrm{H})$, $6.31(\mathrm{td}, J=7.0,1.2 \mathrm{~Hz}, 1 \mathrm{H}) ;{ }^{13} \mathrm{C}$ NMR (100 MHz, DMSO- $\left.d_{6}\right) \delta 161.6$, $161.4,160.5,160.4,141.1,140.8,140.4,139.5,137.0,136.8,121.9,121.3$, $120.2,119.0,118.7,105.7$ (only 16 signals were found); IR (KBr) 3438 , $1677(\mathrm{C}=0), 1659,1612,1574,1537 \mathrm{~cm}^{-1}$. Although the hygroscopic properties of $\mathbf{8}$ prevented us to obtain good results in elemental analysis, the high resolution mass spectrum clearly proved the molecular mass of the molecule. FAB (NBA) $375.1\left(\mathrm{M}^{+}+\mathrm{H}\right)$; HRMS calcd for $\mathrm{C}_{20} \mathrm{H}_{15} \mathrm{~N}_{4} \mathrm{O}_{4}$ : 375.1093, found: $375.1091\left(\mathrm{M}^{+}+\mathrm{H}\right)$.

\subsection{4. $6^{\prime \prime \prime \prime}$-tert-Butoxy-[1,3': $\left.1^{\prime}, 3^{\prime \prime}: 1^{\prime \prime}, 3^{\prime \prime \prime}: 1^{\prime \prime \prime}, 3^{\prime \prime \prime \prime}\right]$ quinquepyridine-} $2,6^{\prime}, 6^{\prime \prime}, 6^{\prime \prime \prime}$-tetraone $(\mathbf{9})$

To an oven-dried double-necked flask (A) (10 mL) containing a stir-bar were charged $8(0.2 \mathrm{~g}, 0.5 \mathrm{mmol})$, CuI $(20 \mathrm{~mol} \%)$, and 
$\mathrm{K}_{2} \mathrm{CO}_{3}$ (2 equiv). The flask was heated to $75^{\circ} \mathrm{C}$ under vacuum for $1 \mathrm{~h}$. To another oven-dried double-necked flask (B) $(10 \mathrm{~mL})$ was charged 18 -crown-6 $(0.094 \mathrm{~g}, 0.1 \mathrm{mmol})$. The crown ether was dried under vacuum at $100{ }^{\circ} \mathrm{C}$ for $1 \mathrm{~h}$ and dissolved in toluene $(1 \mathrm{~mL})$. The crown ether solution, the solution of 2-tert-butoxy-5bromopyridine $(0.13 \mathrm{~g}, 0.5 \mathrm{mmol})$ in DMF $(2 \mathrm{~mL})$, and DMCDA ( $40 \mathrm{~mol} \%$ ) were then injected into flask $A$. The reaction mixture was stirred and heated at reflux for $24 \mathrm{~h}$. Note that $\mathbf{9}$ is highly hygroscopic and soluble in water. The resulting mixture was cooled to room temperature, diluted with dichloromethane, and filtered with Celite. The collected filtrate was dried and concentrated. The crude product was purified by flash chromatography on silica gel (ethyl acetate $/ \mathrm{MeOH})$ to give 9 as white solid $(0.05 \mathrm{~g}, 18 \%)$. Mp 260$261{ }^{\circ} \mathrm{C} .{ }^{1} \mathrm{H}$ NMR $\left(400 \mathrm{MHz}, \mathrm{CDCl}_{3}\right) \delta 8.09(\mathrm{~d}, J=3.2 \mathrm{~Hz}, 1 \mathrm{H}), 7.61(\mathrm{~d}$, $J=2.8 \mathrm{~Hz}, 1 \mathrm{H}), 7.59(\mathrm{dd}, J=8.8,2.8 \mathrm{~Hz}, 1 \mathrm{H}), 7.53(\mathrm{~s}, 2 \mathrm{H}), 7.50(\mathrm{t}$, $J=2.6 \mathrm{~Hz}, 1 \mathrm{H}), 7.47$ (t, $J=2.6 \mathrm{~Hz}, 1 \mathrm{H}), 7.40-7.45(\mathrm{~m}, 2 \mathrm{H}), 7.26$ (dd, $J=6.8,2.0 \mathrm{~Hz}, 1 \mathrm{H}), 6.69(\mathrm{~d}, J=9.2 \mathrm{~Hz}, 4 \mathrm{H}), 6.62(\mathrm{~d}, J=9.2 \mathrm{~Hz}, 1 \mathrm{H}), 6.26$ $(\mathrm{t}, J=4.6 \mathrm{~Hz}, 1 \mathrm{H}), 1.571(\mathrm{~s}, 9 \mathrm{H}) ;{ }^{13} \mathrm{C}$ NMR $\left(100 \mathrm{MHz}, \mathrm{CDCl}_{3}\right) \delta 163.0$, 161.6, 160.5, 160.3, 142.9, 140.2, 139.3, 138.8, 138.4, 136.6, 136.0, $135.5,135.3,135.0,129.5,121.8,121.5,121.44,121.41,121.0,113.1$, 106.7, 80.6, 28.9 (only 22 signals were found). IR (KBr) 3046, 2946, $1681(C=0), 1668(C=0), 1613,1556,1538 \mathrm{~cm}^{-1}$. Although the hygroscopic properties of $\mathbf{9}$ prevented us to obtain good results in elemental analysis, the high resolution mass spectrum clearly proved the molecular mass of the molecule. FAB (NBA) 524.0 $\left(\mathrm{M}^{+}+\mathrm{H}\right)$. HRMS calcd for $\mathrm{C}_{29} \mathrm{H}_{26} \mathrm{~N}_{5} \mathrm{O}_{5} 524.1934$, found 524.1929 $\left(\mathrm{M}^{+}+\mathrm{H}\right)$.

\subsubsection{Oligomerization with 2-tert-butoxy-5-bromopyridine as the terminal group}

To an oven-dried double-necked flask (A) (10 mL) containing a stir-bar were charged 2-hydroxy-5-bromopyridine $(0.305 \mathrm{~g}$, $1.7 \mathrm{mmol}$ ), $\mathrm{CuI}\left(20 \mathrm{~mol} \%\right.$ ), and $\mathrm{K}_{2} \mathrm{CO}_{3}$ (2 equiv) under nitrogen. Another oven-dried double-necked flask (B) $(10 \mathrm{~mL})$ containing 18 crown-6 (0.094 g, $0.35 \mathrm{mmol})$ was pre-dried under vacuum at $100{ }^{\circ} \mathrm{C}$ for $1 \mathrm{~h}$, followed by injection of xylenes $(1 \mathrm{~mL})$. The crown ether solution, a solution of 2-tert-butoxy-5-bromopyridine $(0.20 \mathrm{~g}$, $0.85 \mathrm{mmol}$ ) in xylenes $(1 \mathrm{~mL})$, and DMCDA (40 mol\%) were then injected into the mixture prepared in flask $A$. The reaction mixture was stirred and heated at reflux for $24 \mathrm{~h}$. The resulting mixture was cooled to room temperature and $\mathrm{MeOH}(5 \mathrm{~mL})$ was added to dissolve the precipitates. The solution was filtered with Celite and concentrated. The crude product was purified by flash chromatography on silica gel (hexane/ethyl acetate/MeOH) to afford compound $\mathbf{1 0}(0.034 \mathrm{~g}, 12 \%)$, compound $\mathbf{3}(0.024 \mathrm{~g}, 12 \%)$, compound $5(0.019 \mathrm{~g}, 7 \%)$, compound $11(0.067 \mathrm{~g}, 30 \%)$, and compound 7 (0.015 g, 4\%). Analytical data for 10: mp $130-131{ }^{\circ} \mathrm{C}$. ${ }^{1} \mathrm{H}$ NMR $\left(100 \mathrm{MHz}, \mathrm{CDCl}_{3}\right) \delta 8.04(\mathrm{~d}, J=2 \mathrm{~Hz}, 1 \mathrm{H}), 7.54(\mathrm{dd}, J=8.8,2.8 \mathrm{~Hz})$, $7.38-7.44(\mathrm{~m}, 2 \mathrm{H}), 6.69(\mathrm{~d}, J=8.8 \mathrm{~Hz}, 1 \mathrm{H}), 6.55(\mathrm{~d}, J=10.4 \mathrm{~Hz}), 1.58(\mathrm{~s}$, $9 \mathrm{H}) ;{ }^{13} \mathrm{C} \mathrm{NMR}\left(100 \mathrm{MHz}, \mathrm{CDCl}_{3}\right) \delta 162.9,160.3,142.8,142.6,137.2$, 136.0, 129.6, 122.5, 113.1, 98.1, 80.6, 28.8; FAB (NBA) 323.1 $\left(\mathrm{M}^{+}+\mathrm{H}\right)$; HRMS calcd for $\mathrm{C}_{14} \mathrm{H}_{16} \mathrm{BrN}_{2} \mathrm{O}_{2} 323.0395$, found $323.0389\left(\mathrm{M}^{+}+\mathrm{H}\right)$. Anal. Calcd for $\mathrm{C}_{14} \mathrm{H}_{15} \mathrm{BrN}_{2} \mathrm{O}_{2}$ : C, 52.03; $\mathrm{H}, 4.68 ; \mathrm{N}, 8.67$. Found: $\mathrm{C}$, 52.07; H, 4.65; N, 8.63. Analytical data for 11: $\mathrm{mp} 275-276{ }^{\circ} \mathrm{C} .{ }^{1} \mathrm{H}$ $\operatorname{NMR}\left(400 \mathrm{MHz}, \mathrm{CD}_{3} \mathrm{OD}\right) \delta 7.89(\mathrm{~d}, J=2.8 \mathrm{~Hz}, 1 \mathrm{H}), 7.61-7.68(\mathrm{~m}, 3 \mathrm{H})$, 6.54-6.60 (m, 2H); ${ }^{13} \mathrm{C}$ NMR (100 MHz, DMSO- $\left.d_{6}\right) \delta$ 160.7, 159.2, $142.5,139.7,138.6,133.5,120.9,120.3,118.2,96.4$. FAB (NBA) 268.0 $\left(\mathrm{M}^{+}+\mathrm{H}\right)$; HRMS calcd for $\mathrm{C}_{10} \mathrm{H}_{8} \mathrm{BrN}_{2} \mathrm{O}_{2}$ 266.9769, found 266.9766. Anal. Calcd for $\mathrm{C}_{10} \mathrm{H}_{7} \mathrm{BrN}_{2} \mathrm{O}_{2}$ : C, 44.97; $\mathrm{H}, 2.64 ; \mathrm{N}, 10.49$. Found: $\mathrm{C}$, 44.63; $\mathrm{H}, 2.98 ; \mathrm{N}, 10.78$.

\subsubsection{Oligomerization with 2-hydroxypyridine as the terminal group}

To an oven-dried double-necked flask (A) $(25 \mathrm{~mL})$ containing a stir-bar were charged 2-hydroxy-5-bromopyridine $(0.305 \mathrm{~g}$, $1.7 \mathrm{mmol}), 2$-hydroxypyridine (0.042 g, $0.42 \mathrm{mmol}), \mathrm{Cul}$ (20 $\mathrm{mol} \%$, and $\mathrm{K}_{2} \mathrm{CO}_{3}$ (2 equiv). The reagents were heated to $85^{\circ} \mathrm{C}$ for $1.5 \mathrm{~h}$ to desiccate. To another oven-dried double-necked flask (B) $(10 \mathrm{~mL})$ was charged 18 -crown-6 (0.094 g, $0.35 \mathrm{mmol})$. The 18 -crown- 6 was then dried under vacuum at $100{ }^{\circ} \mathrm{C}$ for $1 \mathrm{~h}$. To flask B was injected xylenes $(8 \mathrm{~mL})$ to dissolve the dried crown. The mixture was then injected under nitrogen to the flask $A$, followed by DMCDA (40 $\mathrm{mol} \%$ ). The reaction mixture was stirred and heated at reflux temperature for $24 \mathrm{~h}$. The resulting mixture was cooled to room temperature. $\mathrm{MeOH}(10 \mathrm{~mL})$ was added to dissolve the precipitates. The reaction mixture was filtered with Celite. The filtrate was concentrated. The crude product was purified by flash chromatography on silica gel (EtOAc/MeOH) to afford $4(0.125 \mathrm{~g}, 48 \%), 6$ (0.11 g, 18\%), and 8 (0.04 g, 5\%).

\section{Acknowledgements}

The work was supported by National Science Council [NSC 952113-M-002-021-MY3 and NSC 95-2113-M002-020], thematic project, Academica Sinica, and Ministry of Education, Taiwan. We are also in debt to the High Field Biomacromolecular NMR Core Facility, Academia Sinica for their supportive High Field NMR service.

\section{Supplementary data}

Supplementary data associated with this article can be found in the online version, at doi:10.1016/j.tet.2008.12.024.

\section{References and notes}

1. (a) Seebach, D.; Matthews, J. L. Chem. Commun 1997, 2015; (b) Gellman, S. H. Acc. Chem. Res. 1998, 31, 173; (c) Hill, D. J.; Mio, M. J.; Prince, R. B.; Hughes, T. S.; Moore, J. S. Chem. Rev. 2001, 101, 3893; (d) Cubberley, M. S.; Iverson, B. L. Curr. Opin. Chem. Biol. 2001, 5, 650; (e) Schmuck, C. Angew. Chem., Int. Ed. 2003, 42, 2448; (f) Huc, I. Eur. J. Org. Chem. 2004, 17; (g) Cheng, R. P. Curr. Opin. Struct. Biol. 2004, 14, 512; (h) Sanford, A.; Yamato, K.; Yang, X. W.; Yuan, L. H.; Han, Y. H.; Gong, B. Eur. J. Biochem. 2004, 271, 1416; (i) Licini, G.; Prins, L. J.; Scrimin, P. Eur. J. Org. Chem. 2005, 969; (j) Stone, M. T.; Heemstra, J. M.; Moore, J. S. Acc. Chem. Res. 2006, 39, 11; (k) Li, X.; Yang, D. Chem. Commun. 2006, 3367; (1) Li, Z. T.; Hou, J. L.; Li, C.; Yi, H. P. Chem. Asian J. 2006, 1, 766.

2. (a) Horne, W. S.; Boersma, M. D.; Windsor, M. A.; Gellman, S. H. Angew. Chem., Int. Ed. 2008, 47, 2853; (b) Norgren, A. S.; Arvidsson, P. I. J. Org. Chem. 2008, 73, 5272; (c) Holub, J. M.; Jang, H.; Kirshenbaum, K. Org. Lett. 2007, 9, 3275; (d) Angelo, N. G.; Arora, P. S. J. Am. Chem. Soc. 2005, 127, 17134.

3. (a) Rowan, A. E.; Nolte, R. J. M. Angew. Chem., Int. Ed. 1998, 37, 63; (b) Cheng, R. P.; Gellman, S. H.; Degrado, W. F. Chem. Rev. 2001, 101, 3219; (c) Norgren, A. S.; Zhang, S.; Arvisson, P. I. Org. Lett. 2006, 8, 4533; (d) Shin, S. B. Y.; Yoo, B.; Todaro, L. J.; Kenshenbaum, K. J. Am. Chem. Soc. 2007, 129, 3218; (e) Barbe, R.; Hasserodt, J. Tetrahedron 2007, 63, 2199; (f) Chien, C.-H.; Leung, M.-k.; Su, J.-K.; Li, G.-H.; Liu, Y.-H.; Wang, Y. J. Org. Chem. 2004, 69, 1866; (g) Leung, M.-k.; Mandal, A. B.; Wang, C.-C.; Lee, G.-H.; Peng, S.-M.; Cheng, H.-L.; Her, G.-R.; Chao, I.; Lu, H. F.; Sun, Y.-C.; Shiao, M.-Y.; Chou, P.-T. J. Am. Chem. Soc. 2002, 124, 4287; (h) Chen, J.-A.; Lai, J.-L.; Lee, G. H.; Wang, Y.; Su, J. K.; Yeh, H.-C.; Lin, W.-Y.; Leung, M.-k. Org. Lett. 2001, 3, 3999; (i) Liao, C.-F.; Lai, J.-L.; Chen, J.-A.; Chen, H.-T.; Cheng, H.-L.; Her, G.-R.; Su, J. K.; Wang, Y.; Lee, G. H.; Leung, M.-k.; Wang, C.-C. J. Org. Chem. 2001, 66, 2566.

4. Huck, B. R.; Fisk, J. D.; Guzei, I. A.; Carlson, H. A.; Gellman, S. H. J. Am. Chem. Soc. 2003, 125, 9035.

5. (a) Williams, A. Chem.-Eur. J. 1997, 3, 15; (b) Piguet, C.; Bernardinelli, G.; Hopfgartner, G. Chem. Rev. 1997, 97, 2005; (c) Dong, Z.; Karpowicz, R. J.; Bai, S.; Yap, G. P. A.; Fox, J. M. J. Am. Chem. Soc. 2006, 128, 14242; (d) Meudtner, R. M.; Ostermeier, M.; Goddard, R.; Limberg, C.; Hecht, S. Chem.-Eur. J. 2007, 13, 9834; (e) Zhang, F.; Bai, S.; Yap, G. P. A.; Tarwade, V.; Fox, J. M. J. Am. Chem. Soc. 2005, 127, 10590; (f) Nicoll, A. J.; Miller, D. J.; Fütterer, K.; Ravelli, R.; Allemann, R. K. J. Am. Chem. Soc. 2006, 128, 9187; (g) Ghosh, S.; Ramakrishnan, S. Macromolecules 2005, 38, 676.

6. (a) Nelson, J. C.; Saven, J. G.; Moore, J. S.; Wolynes, P. G. Science 1997, 277, 1793; (b) Prince, R. B.; Okada, T.; Moore, J. Angew. Chem., Int. Ed. 1999, 38, 233; (c) Gin, M. S.; Yokozawa, T.; Prince, R. B.; Moore, J. S. J. Am. Chem. Soc. 1999, 121, 2643; (d) Hou, J.-L.; Jia, M.-X.; Jiang, X. K.; Li, Z.-T.; Chen, G.-J. J. Org. Chem. 2004, 69, 6228; (e) Cubberley, M. S.; Iverson, B. L. J. Am. Chem. Soc. 2001, 123, 7560; (f) Zhao, Y. Curr. Opin. Colloid Interface Sci. 2007, 12, 92.

7. (a) Petitjean, A.; Nierengarten, H.; Van Dorsselaer, A.; Lehn, J.-M. Angew. Chem., Int. Ed. 2004, 43, 3695; (b) Stadler, A. M.; Kyritsakas, N.; Lehn, J.-M. Chem. Commun. 2004, 2024; (c) Petitjean, A.; Lehn, J.-M. Inorg. Chim. Acta 2007, 360, 849. 
8. (a) Prince, R. B.; Brunsveld, L.; Meijer, E. W.; Moore, J. S. Angew. Chem., Int. Ed. 2000, 39, 228; (b) Sinkeldam, R. W.; van Houten, M. H. C. J.; Pieterse, K.; Vekemans, J. A. J. M.; Meijer, E. W. Chem.-Eur. J. 2006, 12, 6129.

9. (a) Tanatani, A.; Mio, M. J.; Moore, J. S. J. Am. Chem. Soc. 2001, 123, 1792; (b) Wilson, A. J.; Masuda, M.; Sijbesma, R. P.; Meijer, E. W. Angew. Chem., Int. Ed. 2005, 44, 2275.

10. (a) Prince, R. B.; Saven, J. G.; Wolynes, P. G.; Moore, J. S. J. Am. Chem. Soc. 1999, 121, 3114; (b) Prince, R. B.; Barnes, S. A.; Moore, J. S. J. Am. Chem. Soc. 2000, 122, 2758; (c) Inouye, M.; Waki, M.; Abe, H. J. Am. Chem. Soc. 2004, 126, 2022.
11. (a) Yang, X.; Brown, A. L.; Furukawa, M.; Li, S.; Gardinier, W. E.; Bukowski, E. J.; Bright, F. V.; Zheng, C.; Zeng, X. C.; Gong, B. Chem. Commun. 2003, 56; (b) Hu, Z.-Q.; Hu, H.-Y.; Chen, C.-F. J. Org. Chem. 2005, 71, 1131; (c) Sinkeldam, R. W.; van Houtem, M. H. C. J.; Koechelberghs, G.; Vekemans, J. A. J. M.; Meijer, E. W. Org. Lett. 2006, 8, 383; (d) Rodriguez, J. M.; Hamilton, A. D. Angew. Chem., Int. Ed. 2007, 46, 8614.

12. (a) Wang, P.-S.; Liang, C.-K.; Leung, M.-k. Tetrahedron 2005, 61, 2931; (b) Lee, C.-C.; Wang, P.-S.; Viswanath, M. B.; Leung, M.-k. Synthesis 2008, 9, 1359.

13. Strieter, E. R.; Blackmond, D. G.; Buchwald, S. L. J. Am. Chem. Soc. 2005, 127, 4120. 